\title{
Pengaruh Sikap Profesional, Kompetensi Guru, Pendidikan Dan Pelatihan Terhadap Kinerja Guru SMK Di Kecamatan Polewali Kabupaten Polewali Mandar
}

\author{
Ayyub Daeng Pananrang \\ Institut Agama Islam DDI Polewali Mandar
}

\begin{abstract}
ABSTRAK
Penelitian ini bertujuan menjelaskan pengaruh secara signifikan variabel sikap profesional, kompetensi guru dan pendidikan dan pelatihan terhadap kinerja guru SMK di kecamatan Polewali kabupaten Polman, serta mengetahui variabel yang berpengaruh secara dominan diantara tiga variabel sikap profesional, kompetensi guru dan pendidikan dan pelatihan terhadap kinerja guru SMK di kecamatan Polewali kabupaten Polman.

Sampel sebanyak seratus tiga puluh enam orang yang dipilih secara proporsional random sampling dimana sampel diambil secara acak pada populasi pada berbagai unit kerja. Pengumpulan data dilakukan dengan cara memberikan kuesioner/angket kepada guru yang sesuai dengan penelitian yang dilakukan. Data dianalisis menggunakan metode kuantitatif.

Hasil penelitian menunjukkan bahwa secara bersama-sama sikap profesional, kompetensi guru dan pendidikan dan pelatihan berpengaruh signifikan terhadap kinerja guru SMK di kecamatan Polewali kabupaten Polman. Variabel sikap profesional, kompetensi guru dan pendidikan dan pelatihan koefisien regresi yang bertanda positif $(+)$ menandakan hubungan yang searah. Dengan kata lain, sikap profesional, kompetensi guru dan pendidikan dan pelatihan akan meningkatkan kinerja guru SMK di kecamatan Polewali kabupaten Polman. Korelasi atau hubungan antara sikap profesional, kompetensi guru dan pendidikan dan pelatihan dengan kinerja guru SMK di kecamatan Polewali kabupaten Polman adalah sangat kuat sebesar $(\mathrm{r}=0,801)$ dan koefisien determinasi atau angka R square adalah sebesar 0,641. Dan secara individual hasil penelitian menunjukkan (1) Ada pengaruh yang signifikan antara sikap profesional terhadap kinerja guru SMK di kecamatan Polewali kabupaten Polman yang ditunjukkan dari nilai $t_{\text {hitung }}>t_{\text {tabel }}(7,235>1,978)$ atau signifikansi $0,000<0,05$ sehingga dalam pengujian ini menunjukkan bahwa $\mathrm{H}_{\mathrm{a}}$ diterima dan $\mathrm{H}_{0}$ ditolak. (2) Ada pengaruh yang signifikan antara kompetensi guru terhadap kinerja guru SMK di kecamatan Polewali kabupaten Polman yang ditunjukkan dari nilai $t_{\text {hitung }}>t_{\text {tabel }}(6,999>1,978)$ atau signifikansi $0,000<0,05$ sehingga dalam pengujian ini menunjukkan bahwa $\mathrm{H}_{a}$ diterima dan $\mathrm{H}_{0}$ ditolak. (3) Ada pengaruh yang signifikan antara pendidikan dan pelatihan terhadap kinerja guru SMK di kecamatan Polewali kabupaten Polman yang ditunjukkan dari nilai $t_{\text {hitung }}>t_{\text {tabel }}(3,466>1,978)$ atau signifikansi $0,001<$ 0,05 sehingga dalam pengujian ini menunjukkan bahwa $\mathrm{H}_{\mathrm{a}}$ diterima dan $\mathrm{H}_{0}$ ditolak. Dan adapun variabel kompetensi guru yang mempunyai pengaruh paling dominan dalam meningkatkan kinerja guru SMK di Kecamatan Polewali Kabupaten Polman, karena diperoleh angka koefisien regresi yang lebih besar dari variabel lainnya $(\beta=0,347)$.
\end{abstract}

Kata Kunci : Sikap Profesional, Kompetensi Guru, Pendidikan dan Pelatihan, Kinerja Guru. 


\section{PENDAHULUAN}

\section{A. Latar Belakang}

Pendidikan merupakan bidang yang sangat penting dan memiliki peluang karena setiap orang memerlukan pendidikan. Salah satu faktor penunjang pendidikan adalah manusia dalam hal ini adalah Sumber Daya Manusia. Lembaga pendidikan akan berhasil jika memiliki SDM yang berkualitas dan profesional. Menurut Rivai (2005: 309) bahwa kinerja karyawan/guru merupakan suatu hal yang sangat penting dalam upaya perusahaan/lembaga untuk mencapai tujuannya. Lembaga pendidikan selalu berupaya untuk mencapai tujuan organisasinya dengan sebaik-baiknya, agar dapat mencapai tujuan tersebut salah satunya adalah meningkatkan komitmen organisasional para guru yang ada.

Salah satu upaya pelaksanaan pengembangan SDM adalah peningkatan mutu pendidikan. Hal ini disebabkan, pendidikan merupakan alat kunci untuk membentuk SDM yang mandiri dan berkualitas. Peningkatan mutu pendidikan pada hakikatnya tanggung jawab segenap bangsa. Dalam meningkatkan mutu pendidikan harus memperlihatkan komponen-komponen pendidikan,seperti yang dinyatakan La Sulo (2005:60-61) menyatakan sejumlah komponen pendidikan yaitu masukan mentah (raw input) yaitu murid yang akan diproses menjadi tamatan (out put), masukan instrumental (instrumental input) berupa guru, tenaga non guru, administrasi sekolah, kurikulum, anggaran pendidikan, prasarana dan saran, dan masukan lingkungan (environmental input) berupa corak budaya dan kondisi ekonomi masyarakat sekitar, kependudukan, politik dan keamanan negara.

Komponen-komponen pendidikan tersebut memiliki peran penting. Salah satu peran penting ada pada guru, karena merupakan ujung tombak dalam proses pembelajaran. Guru menduduki posisi yang sangat strategis yang akan memberikan kontribusi langsung terhadap kualitas hasil belajar siswa. Seperti yang dinyatakan Aqib (2002 : 22) bahwa guru adalah faktor penentu bagi keberhasilan pendidikan di sekolah, karena guru merupakan sentral serta sumber kegiatan belajara mengajar. Lebih lanjut dinyatakan Djmarah (2002:32) bahwa guru merupakan komponen yang berpengaruh dalam peningkatan mutu pendidikan di sekolah. Dengan demikian jelas bahwa salah satu faktor yang mempengaruhi keberhasilan pendidikan adalah guru. Jika para guru tersebut menjalankan prinsiprinsip profesionalisme dalam menjalankan tugas dan fungsinya akan menghasilkan kinerja yang baik.

Guru adalah orang yang paling penting statusnya di dalam kegiatan belajar mengajar karena guru memegang tugas yang amat penting, yaitu mengatur dan mengemudikan bahtera kehidupan kelas. Bagaimana suasana kelas berlangsung merupakan hasil dari kerja guru. Suasana kelas dapat "hidup", siswa belajar tekun tatapi tidak merasa tertekan, atau sebaliknya, suasana kelas "suram", siswa kurang bersemangat dan diliputi rasa takut, itu semua sebagai akibat dari hasil pemikiran dan upaya guru (Suharsimi, 2009:293). Dengan demikian guru memiliki peran penting dalam mengelola kondisi kelas guna mencapai tujuan yang ingin dicapai.

Kegiatan pembelajaran, dan hasil belajar peserta didik tidak saja ditentukan oleh manajemen sekolah, kurikulum, sarana dan prasarana pembelajaran, tetapi sebagaian besar ditentukan oleh guru.Baik dan jeleknya prestasi siswa tergantung dari kinerja guru (Yamin, 2010:23). Keberhasilan guru dalam proses pembelajaran sangat ditentukan oleh kinerja guru sebagai pendidik. Kinerja guru adalah seluruh usaha guru untuk mengantarkan proses pembelajaran mencapai tujuan pendidikan, 
meliputi kegiatan yang menyangkut tugas profesionalnya sebagai guru dan tugas pengembangan pribadi guru. Menurut Soedijarto (dalam Kunandar,2007:57) Tugas profesional guru mencakup suatu rentetan kegiatan, dimulai dari kegiatan merencanakan pengajaran, menyajikan, mengevaluasi, hingga memberikan tindak lanjut dari hasil evaluasi. Tugas pengembangan pribadi guru bertujuan untuk meningkatkan kemampuan profesi dan akademis berupa kegiatan-kegiatan yang diarahkan untuk menambah, memperluas, dan memperdalam ilmu yang ditekuni, melatih berbagai keterampilan dan keahlian menggunakan berbagai metode pengajaran, meningkatkan keahlian dalam menggunakan dan memanfaatkan teknologi pendidika, serta aktivitas-aktivitas dalam berbagai komunitas masyarakat ilmiah.

Profesionalitas guru pada intinya adalah kompetensi yang dipersyaratkan untuk melakukan tugas pendidikan dan pengajaran. Menurut Asahan (dalam Mulyasa, 2007), kompetensi dapat diartikan pengetahuan, keterampilan dan kemampuan yang dikuasai oleh seseorang yang telah menjadi bagian dari darinya sehingga dia dapat melakukan perilaku-perilaku kognitif, afektif, dan psikomotorik dengan sebaik-baiknya. Kompetensi juga dapat diartikan sebagai pengetahuan, keterampilan, dan nilai-nilai dasar yang direfleksikan dalam kebiasaan berfikir dan bertindak. Dengan demikian kompetensi yang dimiliki oleh setiap guru akan menunjukkan kualitas guru yang sebenarnya (Direktorat Tenaga Kependidikan Depdiknas 2003).

Lebih lanjut Gordon (dalam Mulyasa, 2007) merinci beberapa aspek atau ranah yang ada dalam aspek kompetensi, yakni pertama, pengetahuan yaitu kesadaran dalam bidang kognitif. Kedua, pemahaman: kedalaman kognitif dan afektif yang dimiliki oleh individu. Ketiga, kemampuan yaitu suatu sesuatu yang dimiliki oleh seseorang untuk melakukan tugas atau pekerjaan yang dibebankan kepadanya.Keempat, nilai yaitu suatu standar perilaku yang telah diyakini dan secara psikologis telah menyatu dalam diri seseorang.Kelima, sikap yaitu perasaan (senang-tidak senang, suka-tidak suka) atau reaksi terhadap suatu rangsangan yang datang dari luar.Keenam, minat yaitu kecenderungan seseorang untuk melakukan suatu perbuatan.

Menurut Pusposutarjo (dalam kunandar, 2007:53), seseorang dianggap kompeten apabila telah memenuhi persyaratan: (1) landasan kemampuan pengembangan kepribadian; (2) kemampuan penguasaan ilmu dan keterampilan; (3) kemampuan berkarya; (4) kemampuan menyikapi dan berperilaku dalam berkarya sehingga dapat mandiri, menilai, dan mengambil keputusan secara bertanggung jawab; (5) dapat hidup bermasyarakat dengan bekerja sama, saling menghormati dan menghargai nilai-nilai pluralisme serta kedamaian. Standar kompetensi guru meliputi empat komponen, yaitu: (1) penelolaan pembelajaran; (2) pengembangan potensi; (3) penguasaan akademik; (4) sikap keseluruhan standar kompetensi guru terdiri dari tujuh kompetensi, yaitu: (1) penyusunan rencana pembelajaran; (2) pelaksanaan interaksi belajar mengajar; (3) penilaian prestasi belajar pesrta didik; (4) pelaksanaan tindak lanjut hasil penilaian prestasi belajar peserta didik; (5) pengembangan profesi; (6) pemahaman wawasan pendidikan; (7) penguasaan bahan kajian akademik (Direktorat Tenaga Kependidikan Depdiknas, 2003).

Menurut Suparlan (2005), upaya peningkatan mutu pendidik dan tenaga kependidikan tidak dapat dilepaskan dengan aspek-aspek penting sebagai berikut : (1) gaji dan standar kesejahteraan yang layak untuk kehidupan, (2) standar kualifikasi, (3) standar kompetensi dan upaya peningkatannya, (4) sistem sertifikasi pendidik dan tenaga kependidikan dan alih profesi yang tidak 
memenuhi standar kompetensi, (5) seleksi yang jujur dan transparan, (6) standar pembinaan karir, (7) penyiapan calon pendidik dan tenaga kependidikan yang selaras dengan standar kompetensi dan lebih menekankan praktik mengajar daripada teori semata-mata, (8) sitem diklat dilembaga inservice training dan pendidikan profesi di LPTK, on the job training (OTJ) di sekolah, dan (9) pemberdayaan organisasi pembinaan profesional seperti KKG, MGMP,MKKS, dan MKPS.

Kinerja mempunyai spesifikasi /kriteria tertentu. Kinerja guru dapat dilihat dan diukur berdasarkan spesifikasi/kriteria kompetensi yang harus dimiliki guru.Di dalam kinerja guru terdapat beberapa kompetensi yaitu kompetensi pedagogik, kompetensi pribadi, kompetensi sosial, kompetensi profesional. Agar kinerja guru meningkat perlu diberi peluang atau kesempatan dalam mengembangkan segenap potensinya misalnya melalui peningkatan pendidikan, diikutsertakan dalam kegiatan seminar, lokakarya, MGMP, PLPG, UKA/UKG, PKB, serta pelatihan pendidikan lainnya. Melalui kegiatan - kegiatan tersebut diharapkan kinerja guru akan meningkat dengan semakin baiknya pelaksanaan kegiatan belajar mengajar, termasuk juga kemampuan memanfaatkan teknologi informasi (IT) untuk kepentingan pembelajaran.

Peningkatan mutu pendidikan pada hakikatnya tanggung jawab segenap bangsa, namun sorotan masyarakat dan berbagai media massa menunjukkan bahwa rendahnya mutu pendidikan senantiasa diasumsikan dengan rendahnya kinerja tenaga kependidikan, khususnya guru sebagai pengelolah dan pelaksana langsung proses pembelajaran di kelas. Proses pendidikan dan pengajaran yang dilakukan pada lembaga formal memberikan tanggung jawab pada masing-masing guru bidang studi yang bertindak langsung di depan siswa.

Perkembangan baru terhadap pandangan pembelajaran membawa konsekuensi kepada guru untuk meningkatkan peranan guru sebagai pelaksana pembelajaran, karena pembelajaran dan hasil belajar siswa sebagian besar ditentukan oleh peranan dan kompetensi guru. Guru yang berkompetensi akan lebih mampu mengelola kelasnya sehingga hasil belajar siswa berada pada tingkat optimal. Diasumsikan bahwa keberhasilan setiap guru mata pelajaran pada suatu lembaga pendidikan formal dapat memengaruhi keberhasilan pendidikan dan pengajaran pada umumnya.

Kinerja seseorang dipengaruhi oleh berbagai faktor yang dapat dikelompokkan menjadi dua, yaitu faktor individu dan faktor lingkungan organisasi. Faktor individu meliputi : kemampuan, kebutuhan, kepercayaan, sikap, pengalaman, dan sebagainya. Sedangkan faktor lingkungan organisasi meliputi tugas-tugas, wewenang, tanggung jawab, sistem pengendalian, kepemimpinan dan sebagainya.

Dengan demikian, dapat dipahami bahwa faktor yang serius untuk diteliti sehubungan dengan rendahnya mutu pendidikan adalah masalah kinerja guru yang sangat menentukan pelaksanaan kegiatan pendidikan dan pengajaran di suatu sekolah, sehingga studi tentang kinerja guru dalam pelaksanaan pendidikan dan pengajaran dianggap perlu dilakukan dalam mengkaji model pembelajaran yang ideal dalam pencapaian tujuan secara maksimal.

Berdasarkan uraian diatas, maka penulis ingin meneliti seberapa besar pengaruh sikap profesional, kompetensi guru dan pendidikan dan pelatihan (diklat) terhadap kinerja guru SMK di Kecamatan Polewali Kabupaten Polewali Mandar.

\section{B. Rumusan Masalah}


1. Apakah sikap profesional berpengaruh signifikan terhadap kinerja guru SMK di Kecamatan Polewali Kabupaten Polman?

2. Apakah kompetensi guru berpengaruh signifikan terhadap kinerja guru SMK di Kecamatan Polewali Kabupaten Polman?

3. Apakah pendidikan dan pelatihan (diklat) berpengaruh signifikan terhadap kinerja guru SMK di Kecamatan Polewali Kabupaten Polman?

4. Apakah sikap profesional, kompetensi guru dan diklat secara simultan berpengaruh signifikan terhadap kinerja guru SMK di Kecamatan Polewali Kabupaten Polman?

\section{B. Tujuan Penelitian}

1. Untuk mengetahui pengaruh sikap profesional terhadap kinerja guru SMK di Kecamatan Polewali Kabupaten Polman.

2. Untuk mengetahui pengaruh kompetensi guru terhadap kinerja guru SMK di Kecamatan Polewali Kabupaten Polman.

3. Untuk mengetahui pengaruh pendidikan dan pelatihan (diklat) terhadap kinerja guru SMK di Kecamatan Polewali Kabupaten Polman.

4. Untuk mengetahui pengaruh sikap profesional, kompetensi guru dan pendidikan dan pelatihan (diklat) secara simultan terhadap kinerja guru SMK di Kecamatan Polewali Kabupaten Polman.

\section{Hipotesis}

1. Terdapat pengaruh yang signifikan variabel sikap profesional terhadap kinerja guru SMK di Kecamatan Polewali Kabupaten Polman.

2. Terdapat pengaruh yang signifikan variabel kompetensi guru terhadap kinerja guru SMK di Kecamatan Polewali Kabupaten Polman.

3. Terdapat pengaruh yang signifikan variabel pendidikan dan pelatihan (diklat) terhadap kinerja guru SMK di Kecamatan Polewali Kabupaten Polman.

4. Terdapat pengaruh yang signifikan variabel sikap profesional, kompetensi guru dan diklat terhadap kinerja guru SMK di Kecamatan Polewali Kabupaten Polman.

\section{METODE PENELITIAN}

Penelitian ini merupakan penelitian kausal komparatif yang bertujuan mengidentifikasi fakta atau peristiwa tersebut sebagai variabel yang dipengaruhi (variabel dependen) dan melakukan penyelidikan terhadap variabel-variabel yang mempengaruhinya (variabel independen).

Populasi dalam penelitian ini adalah guru SMK yang ada di Kecamatan Polewali Kabupaten Polman dengan jumlah guru 206 orang dari 7 sekolah kejuruan menengah. Jumlah sampel yang diambil dari populasi guru SMK di Kecamatan Polewali Kabupaten Polman yaitu sebanyak 136 orang dengan teknik proporsional random sampling. 
Variabel dalam penelitian ini terdiri atas variabel bebas dan variabel terikat. Variabel bebas terdiri atas sikap profesional $\left(\mathrm{X}_{1}\right)$, kompetensi guru $\left(\mathrm{X}_{2}\right)$, diklat $\left(\mathrm{X}_{3}\right)$, dan sebagai variabel terikat $(\mathrm{Y})$ dalam penelitian ini adalah kinerja guru.

Teknik pengumpulan data yang digunakan dalam penelitian ini adalah teknik kuesioner. Teknik analisis data yang digunakan dalam penelitian ini adalah analisis statistik deskriptif dan analisis statistik inferensial menggunakan regresi linier berganda.

\section{HASIL PENELITIAN DAN PEMBAHASAN}

\section{A. Analisis Deskriptif Variabel Penelitian}

\section{Sikap Profesional}

Sikap profesional terdiri dari 7 indikator yaitu terampil dalam mengajar, berwawasan yang luas, penguasaan kurikulum, penguasaan media pembelajaran, penguasaan teknologi, berkepribadian dan menjadi teladan yang baik.

Tabel 1. Persentase Sikap Profesional

\begin{tabular}{|c|c|c|c|c|c|c|c|c|c|c|}
\hline \multirow{2}{*}{ No } & \multirow{2}{*}{ Indikator } & \multirow{2}{*}{ No Item } & \multicolumn{5}{|c|}{ Jawaban } & \multirow{2}{*}{$\begin{array}{l}\text { Jumlah } \\
\text { skor }\end{array}$} & \multirow{2}{*}{$\%$} & \multirow{2}{*}{ Kriteria } \\
\hline & & & 1 & 2 & 3 & 4 & 5 & & & \\
\hline \multirow[t]{4}{*}{1} & \multirow{4}{*}{$\begin{array}{l}\text { keterampilan } \\
\text { dalam mengajar }\end{array}$} & 1 & 0 & 12 & 16 & 84 & 24 & 528 & 77.65 & Baik \\
\hline & & 2 & 0 & 7 & 29 & 72 & 28 & 529 & 77.79 & Baik \\
\hline & & 3 & 0 & 7 & 20 & 80 & 29 & 539 & 79.26 & Baik \\
\hline & & Jumlah & 0 & 26 & 65 & 236 & 81 & 1596 & 78,24 & Baik \\
\hline \multirow[t]{4}{*}{2} & \multirow{4}{*}{$\begin{array}{l}\text { berwawasan yang } \\
\text { luas }\end{array}$} & 4 & 0 & 4 & 21 & 87 & 24 & 539 & 79.26 & Baik \\
\hline & & 5 & 0 & 3 & 17 & 81 & 35 & 556 & 81.76 & Baik \\
\hline & & 6 & 0 & 3 & 20 & 81 & 32 & 550 & 80.88 & Baik \\
\hline & & Jumlah & 0 & 10 & 58 & 249 & 91 & 1645 & 80.64 & Baik \\
\hline \multirow[t]{2}{*}{3} & \multirow{2}{*}{$\begin{array}{l}\text { Penguasaan } \\
\text { Kurikulum }\end{array}$} & 7 & 0 & 4 & 13 & 97 & 22 & 545 & 80.15 & Baik \\
\hline & & Jumlah & 0 & 4 & 13 & 97 & 22 & 545 & 80,15 & Baik \\
\hline \multirow[t]{2}{*}{4} & \multirow{2}{*}{$\begin{array}{l}\text { Penguasaan media } \\
\text { pembelajaran/ } \\
\text { teknologi }\end{array}$} & 8 & 0 & 0 & 17 & 94 & 25 & 552 & 81.18 & Baik \\
\hline & & Jumlah & 0 & 0 & 17 & 94 & 25 & 552 & 81.18 & Baik \\
\hline \multirow[t]{5}{*}{5} & \multirow[t]{5}{*}{ Berkepribadian } & 9 & 0 & 7 & 23 & 93 & 13 & 520 & 76.47 & Baik \\
\hline & & 10 & 0 & 1 & 19 & 92 & 24 & 547 & 80.44 & Baik \\
\hline & & 11 & 0 & 0 & 20 & 98 & 18 & 542 & 79.71 & Baik \\
\hline & & 12 & 0 & 1 & 27 & 84 & 24 & 539 & 79.26 & Baik \\
\hline & & Jumlah & & 9 & 89 & 367 & 79 & 2148 & 78.97 & Baik \\
\hline \multirow[t]{3}{*}{6} & \multirow{3}{*}{$\begin{array}{l}\text { Menjadi teladan } \\
\text { yang baik }\end{array}$} & 13 & 0 & 3 & 15 & 93 & 25 & 548 & 80.59 & Baik \\
\hline & & 14 & 0 & 1 & 28 & 87 & 20 & 534 & 78.53 & Baik \\
\hline & & Jumlah & 0 & 4 & 43 & 180 & 45 & 1082 & 79.56 & Baik \\
\hline & & & & & & & & & 79.50 & Baik \\
\hline
\end{tabular}

Sumber : Hasil pengolahan data, 2016.

Berdasarkan tabel di atas dapat dilihat bahwa sikap profesional guru secara keseluruhan tergolong baik dengan persentase 79,50\% (rentang 68,01 - 84,00). Dilihat dari jawaban responden pada setiap item pernyataan kuesioner, seluruh 14 item pertanyaan dengan tanggapan responden tergolong baik.

\section{Kompetensi Guru}


Kompetensi guru terdiri dari 4 indikator yaitu kompetensi pedagogik, kompetensi kepribadian, kompetensi sosial dan kompetensi profesional.

Tabel 2. Persentase Kompetensi Guru

\begin{tabular}{|c|c|c|c|c|c|c|c|c|c|c|}
\hline \multirow{2}{*}{ No } & \multirow{2}{*}{ Indikator } & \multirow{2}{*}{ No item } & \multicolumn{5}{|c|}{ Jawaban } & \multirow{2}{*}{$\begin{array}{l}\text { Jumla } \\
\text { h skor }\end{array}$} & \multirow{2}{*}{$\%$} & \multirow{2}{*}{ Kriteria } \\
\hline & & & 1 & 2 & 3 & 4 & 5 & & & \\
\hline \multirow[t]{5}{*}{1} & \multirow{5}{*}{$\begin{array}{l}\text { Penguasaan } \\
\text { kompetensi } \\
\text { pedagogic }\end{array}$} & 1 & 0 & 0 & 2 & 81 & 53 & 595 & 87.50 & Sangat Baik \\
\hline & & 2 & 0 & 2 & 30 & 91 & 13 & 523 & 76.91 & Baik \\
\hline & & 3 & 0 & 0 & 3 & 74 & 59 & 600 & 88.24 & Sangat Baik \\
\hline & & 4 & 0 & 11 & 23 & 80 & 22 & 521 & 76.62 & Baik \\
\hline & & Jumlah & 0 & 13 & 58 & 326 & 147 & 2239 & 82.32 & Baik \\
\hline \multirow[t]{6}{*}{2} & \multirow{6}{*}{$\begin{array}{l}\text { Penguasaan } \\
\text { kompetensi } \\
\text { Profesional }\end{array}$} & 5 & 0 & 0 & 4 & 66 & 66 & 606 & 89.12 & Sangat Baik \\
\hline & & 6 & 0 & 21 & 22 & 73 & 20 & 500 & 73.53 & Baik \\
\hline & & 7 & 0 & 0 & 3 & 71 & 62 & 603 & 88.68 & Sangat Baik \\
\hline & & 8 & 0 & 9 & 25 & 79 & 23 & 524 & 77.06 & Baik \\
\hline & & 9 & 0 & 0 & 4 & 82 & 50 & 590 & 86.76 & Sangat Baik \\
\hline & & Jumlah & 0 & 30 & 58 & 371 & 221 & 2823 & 83.03 & Baik \\
\hline \multirow[t]{3}{*}{3} & \multirow{3}{*}{$\begin{array}{l}\text { Penguasaan } \\
\text { kompetensi } \\
\text { Kepribadian }\end{array}$} & 10 & 0 & 10 & 16 & 90 & 20 & 528 & 77.65 & Baik \\
\hline & & 11 & 0 & 0 & 2 & 71 & 63 & 605 & 88.97 & Sangat Baik \\
\hline & & Jumlah & 0 & 10 & 18 & 161 & 83 & 1133 & 83.31 & Baik \\
\hline \multirow[t]{4}{*}{4} & \multirow{4}{*}{$\begin{array}{l}\text { Penguasaan } \\
\text { kompetensi Sosial }\end{array}$} & 12 & 0 & 8 & 21 & 86 & 21 & 528 & 77.65 & Baik \\
\hline & & 13 & 0 & 0 & 3 & 72 & 61 & 602 & 88.53 & Sangat Baik \\
\hline & & 14 & 0 & 16 & 22 & 86 & 12 & 502 & 73.82 & Baik \\
\hline & & Jumlah & & 24 & 46 & 244 & 94 & 1632 & 80.00 & Baik \\
\hline & & & & & & & & & 82.22 & Baik \\
\hline
\end{tabular}

Sumber : Hasil pengolahan data, 2016.

Berdasarkan tabel di atas dapat dilihat bahwa kompetensi guru secara keseluruhan tergolong baik dengan persentase $82,22 \%$ (rentang $68,01-84,00$ ). Dilihat dari jawaban responden pada setiap item pernyataan kuesioner, terdapat 7 item pertanyaan dengan tanggapan responden tergolong sangat baik sedangkan sisanya 7 item pernyataan menunjukkan persentase skor baik.

\section{Pendidikan dan Pelatihan (Diklat)}

Data mengenai diklat dikumpulkan melalui kuesioner yang terdiri dari 9 item pertanyaan dengan jumlah responden sebanyak 136 orang. Jawaban responden tentang kompetensi keguruan digambarkan dalam tabel 3.

Berdasarkan tabel 3 dapat dilihat bahwa diklat secara keseluruhan tergolong baik dengan persentase 83,66 (rentang 68,01 - 84,00). Dilihat dari jawaban responden pada setiap item pernyataan kuesioner, terdapat 5 item pertanyaan dengan tanggapan responden tergolong sangat baik sedangkan sisanya 5 item pernyataan menunjukkan persentase skor baik.

Tabel 3. Jawaban Responden pada Diklat

\begin{tabular}{|l|c|c|c|c|c|c|c|c|c|c|}
\hline \multirow{2}{*}{ No } & \multirow{2}{*}{ Indikator } & \multirow{2}{*}{ No item } & \multicolumn{5}{|c|}{ Jawaban } & \multirow{2}{*}{ Kumlah } & \% & \multirow{2}{*}{ Kriteria } \\
\cline { 4 - 9 } & & & $\mathbf{1}$ & $\mathbf{2}$ & $\mathbf{3}$ & $\mathbf{4}$ & $\mathbf{5}$ & & \\
\hline & & 1 & 0 & 0 & 2 & 65 & 69 & $\mathbf{6 1 1}$ & 89.85 & Sangat Baik \\
\hline
\end{tabular}




\begin{tabular}{|c|c|c|c|c|c|c|c|c|c|c|}
\hline \multirow[t]{2}{*}{1} & \multirow{2}{*}{ Tingkat reaksi } & 2 & 0 & 0 & 13 & 98 & 25 & 556 & 81.76 & Baik \\
\hline & & Jumlah & 0 & 0 & 15 & 163 & 94 & 1167 & 85.81 & Sangat Baik \\
\hline \multirow[t]{3}{*}{2} & \multirow[t]{3}{*}{ Tingkat belajar } & 3 & 0 & 0 & 3 & 77 & 56 & 597 & 87.79 & Sangat Baik \\
\hline & & 4 & 0 & 0 & 32 & 92 & 12 & 524 & 77.06 & Baik \\
\hline & & Jumlah & & & 35 & 169 & 68 & 11.21 & 82.43 & Baik \\
\hline \multirow[t]{3}{*}{4} & \multirow{3}{*}{$\begin{array}{l}\text { Tingkat tingkah } \\
\text { laku kerja }\end{array}$} & 5 & 0 & 0 & 5 & 89 & 42 & 581 & 85.44 & Sangat Baik \\
\hline & & 6 & 0 & 0 & 3 & 116 & 17 & 558 & 82.06 & Baik \\
\hline & & Jumlah & 0 & 0 & 8 & 205 & 59 & 1139 & 83.75 & Baik \\
\hline \multirow[t]{3}{*}{5} & \multirow{3}{*}{$\begin{array}{l}\text { Tingkat } \\
\text { organisasi }\end{array}$} & 7 & 0 & 0 & 1 & 89 & 46 & 589 & 86.62 & Sangat Baik \\
\hline & & 8 & 0 & 1 & 53 & 71 & 11 & 500 & 73.53 & Baik \\
\hline & & Jumlah & 0 & 1 & 54 & 160 & 57 & 1089 & 80.07 & Baik \\
\hline \multirow[t]{2}{*}{6} & \multirow[t]{2}{*}{ Nilai akhir } & 9 & 0 & 0 & 0 & 76 & 60 & 604 & 88.82 & Sangat Baik \\
\hline & & Jumlah & $\mathbf{0}$ & $\mathbf{0}$ & $\mathbf{0}$ & 76 & 60 & 604 & 88.82 & Sangat Baik \\
\hline & & & & & & & & & 83.66 & Baik \\
\hline
\end{tabular}

Sumber : Hasil pengolahan data, 2016.

\section{Kinerja Guru}

Kinerja guru terdiri dari 3 indikator yaitu merencanakan pembelajaran, melaksanakan proses pembelajaran yang bermutu serta menilai dan mengevaluasi hasil pembelajaran.

Tabel 4. Persentase Kinerja Guru

\begin{tabular}{|c|c|c|c|c|c|c|c|c|c|c|}
\hline \multirow{2}{*}{ No } & \multirow{2}{*}{ Indikator } & \multirow{2}{*}{ No Item } & \multicolumn{5}{|c|}{ Jawaban } & \multirow{2}{*}{$\begin{array}{c}\text { Jumlah } \\
\text { skor }\end{array}$} & \multirow{2}{*}{$\%$} & \multirow{2}{*}{ Kriteria } \\
\hline & & & 1 & 2 & 3 & 4 & 5 & & & \\
\hline \multirow[t]{7}{*}{1} & \multirow{7}{*}{$\begin{array}{l}\text { Perencanaan } \\
\text { pembelajaran }\end{array}$} & 1 & 0 & 0 & 0 & 57 & 79 & 623 & 91.62 & Sangat Baik \\
\hline & & 2 & 0 & 0 & 19 & 86 & 31 & 556 & 81.76 & Baik \\
\hline & & 3 & 0 & 0 & 0 & 57 & 79 & 623 & 91.62 & Sangat Baik \\
\hline & & 4 & 0 & 1 & 25 & 80 & 30 & 547 & 80.44 & Baik \\
\hline & & 5 & 0 & 0 & 0 & 57 & 79 & 623 & 91.62 & Sangat Baik \\
\hline & & 6 & 0 & 3 & 16 & 96 & 21 & 543 & 79.85 & Baik \\
\hline & & Jumlah & 0 & 4 & 60 & 433 & 319 & 3515 & 86.15 & Sangat Baik \\
\hline \multirow[t]{5}{*}{2} & \multirow{5}{*}{$\begin{array}{l}\text { Pelaksanaan } \\
\text { kegiatan } \\
\text { pembelajaran } \\
\text { yang aktif dan } \\
\text { efektif }\end{array}$} & 7 & 0 & 0 & 0 & 58 & 78 & 622 & 91.47 & Sangat Baik \\
\hline & & 8 & 0 & 9 & 26 & 81 & 20 & 520 & 76.47 & Baik \\
\hline & & 9 & 0 & 0 & 1 & 63 & 72 & 615 & 90.44 & Sangat Baik \\
\hline & & 10 & 0 & 15 & 25 & 77 & 19 & 508 & 74.71 & Baik \\
\hline & & Jumlah & 0 & 24 & 32 & 279 & 189 & 2265 & 83.27 & Baik \\
\hline \multirow[t]{7}{*}{3} & \multirow{7}{*}{$\begin{array}{l}\text { Penilaian/evalua } \\
\text { si pembelajaran }\end{array}$} & 11 & 0 & 0 & 2 & 54 & 80 & 622 & 91.47 & Sangat Baik \\
\hline & & 12 & 0 & 33 & 37 & 50 & 16 & 457 & 69.21 & Baik \\
\hline & & 13 & 0 & 0 & 0 & 54 & 82 & 626 & 92.06 & Sangat Baik \\
\hline & & 14 & 0 & 7 & 25 & 63 & 41 & 546 & 80.29 & Baik \\
\hline & & 15 & 0 & 0 & 3 & 65 & 68 & 609 & 89.56 & Sangat Baik \\
\hline & & 16 & 0 & 29 & 30 & 65 & 12 & 468 & 68.82 & Baik \\
\hline & & Jumlah & 0 & 69 & 97 & 351 & 299 & 3328 & 81.57 & Baik \\
\hline & & & & & & & & & 83.71 & Baik \\
\hline
\end{tabular}

Sumber : Hasil pengolahan data, 2016. 
Berdasarkan tabel di atas dapat dilihat bahwa kinerja guru secara keseluruhan tergolong baik dengan persentase $83,71 \%$ (rentang $68,01-84,00$ ). Dilihat dari jawaban responden pada setiap item pernyataan kuesioner, terdapat 8 item pertanyaan dengan tanggapan responden tergolong sangat baik sedangkan sisanya 8 item pernyataan menunjukkan persentase skor baik.

\section{B. Hasil Analisis Inferensial}

\section{Analisis Regresi}

\section{a. Model Regresi Linier Berganda}

Berdasarkan analisis regresi berganda dengan bantuan program SPSS dapat dibuat persamaan regresi linier berganda. Adapun hasil output SPSS tersebut dapat dilihat pada tabel 5 berikut ini:

Tabel 5. Hasil Analisis Regresi Linier Berganda

Coefficients $^{\text {a }}$

\begin{tabular}{|c|c|c|c|c|c|c|c|c|}
\hline \multirow{2}{*}{\multicolumn{2}{|c|}{ Model }} & \multicolumn{2}{|c|}{$\begin{array}{c}\text { Unstandardized } \\
\text { Coefficients }\end{array}$} & \multirow{2}{*}{$\begin{array}{c}\text { Standardized } \\
\text { Coefficients } \\
\text { Beta }\end{array}$} & \multirow[b]{2}{*}{$\mathrm{T}$} & \multirow[b]{2}{*}{ Sig. } & \multicolumn{2}{|c|}{$\begin{array}{c}\text { Collinearity } \\
\text { Statistics }\end{array}$} \\
\hline & & B & Std. Error & & & & Tolerance & VIF \\
\hline \multirow[t]{4}{*}{1} & (Constant) & .511 & .279 & & 1.831 & .069 & & \\
\hline & $\begin{array}{l}\text { Sikap } \\
\text { Profesional }\end{array}$ & .329 & .045 & .422 & 7.235 & .000 & .800 & 1.250 \\
\hline & $\begin{array}{l}\text { Kompetensi } \\
\text { guru }\end{array}$ & .347 & .050 & .419 & 6.999 & .000 & .759 & 1.317 \\
\hline & Diklat & .225 & .065 & .194 & 3.466 & .001 & .865 & 1.156 \\
\hline
\end{tabular}

a. Dependent Variable: Kinerja Guru

Persamaan regresi yang dihasilkan adalah:

$$
\mathrm{Y}=0,511+0,329 \mathrm{X}_{1}+0,347 \mathrm{X}_{2}+0,225 \mathrm{X}_{3}
$$
berikut:

Berdasarkan persamaan regresi linier berganda tersebut, maka dapat diinterpretasikan sebagai

a. Konstanta $\left(\beta_{0}\right)=0,511$, yang menunjukkan bahwa jika variabel sikap profesional, kompetensi guru dan diklat dalam keadaan tetap atau tidak mengalami perubahan, maka kinerja guru adalah sebesar 0,511 satuan.

b. $\beta_{1}=0,329$, yang menunjukkan bahwa jika variabel sikap profesional meningkat sebesar 1 satuan, maka kinerja guru SMK di Kecamatan Polewali Kabupaten Polman akan meningkat sebesar 0,329 satuan.

c. $\beta_{2}=0,347$, yang menunjukkan bahwa jika variabel kompetensi meningkat sebesar 1 satuan, maka kinerja guru SMK di Kecamatan Polewali Kabupaten Polman akan meningkat sebesar 0,347 satuan. 
d. $\beta_{3}=0,225$, yang menunjukkan bahwa jika variabel diklat meningkat sebesar 1 satuan, maka kinerja guru SMK di Kecamatan Polewali Kabupaten Polman akan meningkat sebesar 0,225 satuan.

Berdasarkan uraian di atas dapat diketahui bahwa dari ketiga variabel yang signifikan tersebut, ternyata variabel kompetensi guru yang mempunyai pengaruh paling dominan dalam meningkatkan kinerja guru SMK di Kecamatan Polewali Kabupaten Polman, karena diperoleh angka koefisien regresi yang lebih besar dari variabel lainnya $(0,347)$.

\section{b. Koefisien Korelasi (R) dan Determinasi $\left(\mathbf{R}^{2}\right)$}

Koefisien korelasi (R) digunakan untuk menerangkan keeratan hubungan antara variabelvariabel bebas sikap profesional, kompetensi dan diklat terhadap variabel terikat (kinerja guru), sedangkan koefisien determinasi $\left(\mathrm{R}^{2}\right)$ digunakan untuk menerangkan seberapa besar pengaruh dari seluruh variabel bebas (variabel sikap profesional, kompetensi guru dan diklat terhadap variabel terikat (kinerja guru). Perolehan nilai $\mathrm{R}$ dan $\mathrm{R}^{2}$ dapat dilihat pada tabel 6.

Tabel 6. Hasil Pengujian Koefisien Korelasi (R) dan Determinasi $\left(\mathrm{R}^{2}\right)$

\begin{tabular}{|l|c|r|r|r|r|}
\hline Model & $\mathrm{R}$ & \multicolumn{1}{|c|}{ Model Summary $^{\mathbf{b}}$} \\
\hline 1 & $.801^{\mathrm{a}}$ & .641 & $\begin{array}{c}\text { Adjusted R } \\
\text { Square }\end{array}$ & $\begin{array}{c}\text { Std. Error of } \\
\text { the Estimate }\end{array}$ & Durbin-Watson \\
\hline
\end{tabular}

a. Predictors: (Constant), Diklat, Sikap Profesional, Kompetensi Keguruan

b. Dependent Variable: Kinerja Guru

Sumber : Hasil Analisis Data, 2016

Berdasarkan hasil pengujian koefisien korelasi dan determinasi tersebut di atas, dapat dijelaskan bahwa besarnya koefisien korelasi (R) sebesar 0,801 termasuk dalam kategori hubungan yang sangat kuat (rentang 0,80-1,00) dan koefisien determinasi $\left(R^{2}\right)$ sebesar 0,641, yang menunjukkan bahwa kontribusi variabel sikap profesional, kompetensi guru dan diklat dalam menjelaskan variasi nilai variabel kinerja guru sebesar $64,1 \%$, sedangkan sisanya sebesar 35,9\% dipengaruhi oleh faktor lain yang tidak dimasukkan dalam penelitian ini.

\section{Pengujian Hipotesis}

Pengujian terhadap hasil regresi yang diperoleh dilakukan pengujian secara serempak dengan menggunakan uji-F dan pengujian secara parsial menggunakan uji-t.

\section{a. Pengujian hipotesis secara simultan (Uji F)}

Pengujian secara simultan bertujuan untuk melihat pengaruh variabel sikap profesional, kompetensi guru, dan diklat terhadap kinerja guru SMK di Kecamatan Polewali Kabupaten Polman dapat diketahui dengan melakukan uji ANOVA atau F-test. Uji F dilakukan dengan membandingkan $\mathrm{F}_{\text {hitung }}$ dengan $\mathrm{F}_{\text {tabel. }}$.

\section{Tabel $\mathrm{F}=(\mathrm{k}-1):(\mathrm{n}-\mathrm{k})=(4-1):(136-4)=3: 132$}

Melalui bantuan program SPSS 22 diperoleh hasil uji F sebagaimana yang dapat dilihat pada tabel 7. Berdasarkan data pada tabel 7 (hasil analisis uji ANOVA) dapat dilihat bahwa variabel sikap 
profesional, kompetensi dan diklat nilai $\mathrm{F}_{\text {hitungnya }}$ yang diperoleh sebesar 78,728 dengan tingkat signifikansi 0,000 , sedangkan nilai $\mathrm{F}_{\text {tabel }} \quad(\mathrm{df1}=3 ; \mathrm{df2}=132 ; \alpha=0,05)$ diperoleh 2,673. Dengan demikian, nilai $\mathrm{F}_{\text {hitung }}>\mathrm{F}_{\text {tabel }}$ atau 78,729 $>2,673$ yang berarti nilai ini menyatakan hubungan yang positif dan signifikan pada tingkat signifikansi 5\%. Dengan hasil ini, maka dapat disimpulkan bahwa secara simultan variabel sikap profesional, kompetensi guru dan diklat berpengaruh positif dan signifikan terhadap kinerja guru SMK di Kecamatan Polewali Kabupaten Polman, sehingga hipotesis pertama yang menyatakan bahwa " terdapat pengaruh yang signifikan variabel sikap profesional, kompetensi dan diklat terhadap kinerja guru SMK di Kecamatan Polewali Kabupaten Polman” diterima atau dapat dibuktikan.

Tabel 7. Pengujian Secara Simultan (Uji F)

\begin{tabular}{|ll|r|r|r|r|r|}
\hline Model & & Sum of Squares & \multicolumn{1}{|c|}{ Df } & Mean Square & F & Sig. \\
\hline 1 & Regression & 7.787 & 3 & 2.596 & 78.728 & $.000^{\mathrm{b}}$ \\
& Residual & 4.352 & 132 & .033 & & \\
& Total & 12.139 & 135 & & & \\
\hline
\end{tabular}

a. Dependent Variable: Kinerja Guru

b. Predictors: (Constant), Diklat, Sikap Profesional, Kompetensi Keguruan

Sumber : Hasil Analisis Data, 2016.

\section{b. Pengujian hipotesis secara parsial (Uji-t)}

Pengujian secara parsial digunakan untuk melihat pengaruh variabel sikap profesional, kompetensi guru, dan diklat terhadap kinerja guru SMK di Kecamatan Polewali Kabupaten Polman secara individual dan untuk mengetahui variabel bebas yang mempunyai pengaruh yang dominan terhadap variabel terikat dengan mengukur hubungan antara variabel bebas dengan asusmsi variabel bebas lainnya bersifat tetap atau konstan.

Hasil pengujiannya dapat dilihat pada nilai thitungnya, sedangkan untuk melihat besarnya pengaruh digunakan angka beta atau standardized coefficient. Adapun hasil pengujian secara parsial ( $\mathrm{t}_{\text {hitung }}$ ) dapat dilihat pada Tabel 5 (Coefficients $\left.{ }^{\mathrm{a}}\right)$.

Berdasarkan pengujian secara parsial seperti pada Tabel 5 (Coefficients ${ }^{\mathrm{a}}$ ) menunjukkan variabel sikap profesional, kompetensi guru dan diklat secara individual berpengaruh positif dan signifikan terhadap kinerja guru SMK di Kecamatan Polewali Kabupaten Polman. Hal ini dapat diketahui dari nilai $t_{\text {hitung }}>t_{\text {tabel }}$ yakni 1,978 diperoleh dari $(\mathrm{df}=134 ; \alpha=0,05)$ dan dapat juga dilihat melalui tingkat signifikansinya dimana kolom sig./ probabilitas pada tabel 5.19 diperoleh nilai signifikansi $<0,05$ yaitu variabel sikap profesional, dengan $t_{\text {hitung }} 7,235>1,978$ atau signifikansi $0,000<0,05$, dengan demikian, hipotesis kedua dari penelitian ini yang menyatakan " terdapat pengaruh variabel sikap profesional terhadap kinerja guru SMK di Kecamatan Polewali Kabupaten Polman" diterima. Selanjutnya, variabel kompetensi guru dengan $t_{\text {hitung }} 6,999>1,978$ atau signifikansi $0,000<0,05$, dengan demikian, hipotesis ketiga dari penelitian ini yang menyatakan " terdapat pengaruh variabel kompetensi guru terhadap kinerja guru SMK di Kecamatan Polewali Kabupaten Polman" diterima. Dan terakhir, variabel diklat dengan $t_{\text {hitung }} 3,466>1,978$ atau signifikansi $0,001<$ 0,05 , dengan demikian, hipotesis kedua dari penelitian ini yang menyatakan " terdapat pengaruh 
variabel diklat terhadap kinerja guru SMK di Kecamatan Polewali Kabupaten Polman" diterima. Dari ketiga variabel bebas tersebut, yang memberi pengaruh dominan adalah variabel kompetensi $\operatorname{guru}\left(\mathrm{X}_{2}\right)$.

\section{Pembahasan}

\section{Pengaruh Sikap Profesional Terhadap Kinerja Guru}

Sikap profesional adalah "berkaitan dengan istilahnya, sikap profesional memiliki dua arti kata yaitu sikap dan profesional". Sikap berarti cara/tingkah kita untuk menghadapi sesuatu. Sedangkan profesional merupakan tanggung jawab terhadap suatu pekerjaan yang kita tekuni, komitmen kita terhadap pekerjaan. Jika menggabungkan kedua istilah tersebut menjadi sikap profesional, akan menghasilkan pengertian sikap profesional, yaitu suatu sikap komitmen kita terhadap suatu profesi yang kita jalani atau tekuni. Apabila kita telah menunjukkan sikap tersebut, akan mendapat hasil yang maksimal sesuai dengan harapan kita.

Peningkatan sikap profesional guru sangat ditentukan oleh besarnya peran 7 indikator yang membentuknya, yakni terampil dalam mengajar, berwawasan yang luas, penguasaan kurikulum, penguasaan media pembelajaran, penguasaan teknologi, berkepribadian dan menjadi teladan yang baik.

Hasil pengujian secara parsial menunjukkan variabel sikap profesional berpengaruh positif dan signifikan terhadap kinerja guru SMK di Kecamatan Polewali Kabupaten Polman. Hal ini mengindikasikan ada hubungan searah antara sikap profesional guru dengan kinerja guru, dalam arti jika sikap profesional menjadi lebih baik maka kinerja guru juga cenderung meningkat, dan sebaliknyajika sikap profesional menjadi lebih buruk maka kinerja guru juga cenderung menurun.

Jika diinterpretasi angka ini memberikan indikasi bahwa sikap profesional yang dimiliki guru dalam mengajar selama ini adalah cukup memadai dalam pencapaian tujuan pembelajaran. Artinya, semakin tinggi sikap profesional yang diperlihatkan guru dalam melaksanakan tugas dengan penuh rasa tanggung jawab, maka hasil prestasi belajar siswa juga akan meningkat, karena target pencapaian kurikulum terlaksana dengan baik. Begitu pula sebaliknya jika sikap profesional yang dimiliki guru adalah rendah maka dapat diasumsikan prestasi belajar siswa juga rendah.

Pengukuran sikap profesional seorang guru adalah terciptanya sikap mencintai pekerjaan sebagai seorang guru dalam melaksanakan tugasnya. Soetjipto (2007) menguraikan lebih lanjut bahwa ada beberapa sasaran sikap profesional keguruan dalam menjalankan tugas dan kewajibannya, antara lain : (1) sikap terhadap pekerjaan sebagai seorang guru yang tidak mampu diemban oleh orang lain dalam mencerdaskan anak bangsa, (2) sikap terhadap anak didik, artinya seorang guru harus mampu memiliki sikap kepedulian terhadap perkembangan belajar anak didiknya, (3) sikap terhadap organisasi profesi keguruan, hal ini dimaksudkan sebagai sarana untuk mengembangkan sikap profesional yang lebih matang dalam menyelesaikan setiap permasalahan yang dihadapinya, dan (4) sikap terhadap teman sejawat, yang ditandai dengan adanya saling kerjasama dalam menyelesaikan tugas yang diberikan oleh pimpinan.

\section{Pengaruh Kompetensi Guru Terhadap Kinerja Guru}


Kompetensi guru adalah kemampuan guru untuk mentransfer pengetahuan dan keterampilannya dalam melaksanakan kewajiban pembelajaran secara profesional dan bertanggung jawab. Peningkatan kompetensi guru sangat ditentukan oleh besarnya peran indikator yang membentuknya, yakni: terdiri dari kompetensi pedagogik, kompetensi profesional, kompetensi kepribadian dan kompetensi sosial.

Hasil pengujian secara parsial menunjukkan variabel kompetensi berpengaruh positif dan signifikan terhadap kinerja guru SMK di Kecamatan Polewali Kabupaten Polman. Hal ini mengindikasikan ada hubungan searah antara kompetensi dengan kinerja guru, dalam arti jika kompetensi guru bertambah baik maka kinerja guru juga cenderung meningkat, dan sebaliknya jika kompetensi guru berkurang maka kinerja guru juga cenderung menurun.

Kondisi ini dapat dipengaruhi oleh beberapa faktor, antara lain: (1) tersedianya sarana pengembangan kompetensi guru baik yang ada dalam lingkungan sekolah maupun melalui pendidikan dan pelatihan yang dilakukan oleh pemerintah, (2) adanya dorongan dari kepala sekolah terhadap guru mata pelajaran untuk mengikuti pengembangan kompetensi yang berhubungan dengan uraian tugasnya. Artinya, bentuk dukungan tersebut antara lain, menyediakan fasilitas dana dan waktu kepada guru yang bersangkutan untuk mengikuti kegiatan pengembangan kompetensi tersebut, (3) adanya tuntutan masyarakat terutama orang tua siswa dalam menilai kemampuan guru yang dimiliki dalam meningkatkan prestasi belajar anak didik. Bentuk tuntutan tersebut adalah meningkatnya prestasi belajar siswa, yang pada akhirnya semua peserta didikdinyatakan lulus dalam ujian, dimana ukuran kelulusan siswa dalam belajar, salah satunya nilai mata pelajaran tidak boleh merah atau tidak boleh di bawah standar KKM tiap mata pelajaran, dan (4) hubungan sosial yang harmonis antara pihak sekolah dengan warga masyarakat sekitar sekolah, sehingga memberikan motivasi kepada guru untuk berkompetensi dalam mengembangkan prestasi belajar anak didiknya.

Hasil penelitian ini didukung oleh teori Cagan (1997) bahwa kompetensi yang harus dimiliki oleh seorang guru adalah : (1) adanya kemampuan berfikir kritis dan sistimatis dalam menjalankan tugas, (2) adanya keinginan untuk selalu meningkatkan kemampuan intelektual dalam menguasai bahan pelajaran yang akan diajarkan dalam kelas dan di luar kelas, (3) adanya kemampuan untuk menjalin kerja sama sesama rekan guru dan kepala sekolah dalam proses pembelajaran.

Diperjelas oleh kajian teori yang dikemukakan oleh Robert W.R (dalam Hamalik, 2006) bahwa ada beberapa ciri profesionalisme jabatan guru, antara lain : guru bekerja sebagai pelayan kemanusiaan dalam mencerdaskan anak bangsa, guru dituntut untuk memiliki pengetahuan dan keterampilan yang memadai dalam melaksanakan tugasnya, dan guru harus memiliki kode etik yang harus dijunjung tinggi dalam masyarakat umum sebagai penilaian kinerja guru.

\section{Pengaruh Diklat Terhadap Kinerja Guru}

Diklat adalah serangkaian program yang dirancang untuk meningkatkan pengetahuan dan kemampuan seorang guru yang dilakukan oleh tenaga profesional kepelatihan guna meningkatkan efektivitas dan produktivitas dalam suatu organisasi sekolah. Peningkatan diklat guru sangat ditentukan oleh besarnya peran indikator yang membentuknya, yakni: terdiri dari 5 indikator yaitu (1) tingkat reaksi (2) ringkat belajar (3) tingkat tingkah laku kerja (4) tingkat organisasi (5) nilai akhir. 
Hasil pengujian secara parsial menunjukkan variabel diklat berpengaruh positif dan signifikan terhadap kinerja guru SMK di Kecamatan Polewali Kabupaten Polman. Hal ini mengindikasikan ada hubungan searah antara diklat dengan kinerja guru, dalam arti jika diklat sering dilaksanakan maka kinerja guru juga cenderung meningkat, dan sebaliknya jika diklat jarang dilaksanakan maka kinerja guru juga cenderung menurun.

\section{PENUTUP}

\section{A. Simpulan}

1. Terdapat pengaruh positif dan signifikan variabel sikap profesional terhadap kinerja guru SMK di Kecamatan Polewali Kabupaten Polman $(\mathrm{P}=0,000)$.

2. Terdapat pengaruh positif dan signifikan variabel kompetensi guru terhadap kinerja guru SMK di Kecamatan Polewali Kabupaten Polman $(P=0,000)$.

3. Terdapat pengaruh positif dan signifikan variabel diklat terhadap kinerja guru SMK di Kecamatan Polewali Kabupaten Polman $(\mathrm{P}=0,001)$.

4. Secara simultan, terdapat pengaruh positif dan signifikan variabel sikap profesional, kompetensi guru dan diklat terhadap kinerja guru SMK di Kecamatan Polewali Kabupaten Polman $(\mathrm{P}=0,000)$.

\section{B. Saran}

1. Diharapkan pemerintah berperan lebih aktif dalam meningkatkan kinerja guru, berupa pengalokasian dana khusus untuk meningkatkan sikap profesional guru, kompetensi keguruan, dan pelaksanaan diklat guru secara berkala sehingga di masa mendatang guru-guru bisa menjalankan tugas-tugasnya secara efektif dan efisien.

2. Diharapkan para kepala sekolah mendorong guru-guru agar berlomba-lomba untuk meningkatkan kinerjanya masing-masing dengan jalan menambah wawasan dan keahlian yang berhubungan dengan profesi keguruan melalui kegiatan-kegiatan pengembangan diri yang diadakan oleh pemerintah maupun swasta. Selain itu, diharapkan kepala sekolah memperhatikan kesejahteraan guru-guru dengan jalan mendorong upaya sertifikasi semua guru yang ada di sekolahnya masing-masing.

\section{DAFTAR PUSTAKA}

Arifin. 2014. Kinerja Guru Profesional. Yogyakarta: Ar-Ruzz Media.

Aqib. 2002. Profesionalisme Guru dalam Pembelajaran. Surabaya: Insan Cendekia.

Cagan. 1997. Guru yang Profesional melalui Pendekatan Kompetensi. Jakarta: Rineka Cipta.

Daryanto. 2013. Standar Kompetensi dan Penilaian Kinerja Guru Profesional. Yogyakarta: Gava Media.

Etta M.S. 2010. Metodologi Penelitian Pendekatan Praktis dalam Penelitian. Yogyakarta: Andi Offset. 
Fatah. 2003. Landasan Manajemen Pendidikan. Bandung: Remaja Rosdakarya.

Ghozali. 2011. Aplikasi Analisis Multivariate dengan Program IBM SPSS 19. Semarang: Badan Penerbit Universitas Diponegoro.

Gomes, 2009. Manajemen Sumber Daya Manusia.Yogyakarta: Andi.

Hamalik. 2006. Pendidikan Guru Berdasarkan Pendekatan Kompetensi. Jakarta: Bumi Aksara.

2007. Manajemen Pendidikan, Ketenagakerjaan Pendekatan Terpadu. Jakarta: Bumi Aksara.

Handoko. 2008. Manajemen Personalia dan Sumber Daya Manusia. Yogyakarta: BPFE.

Hasibuan. 2009. Manajemen Sumber Daya Manusia. Jakarta: Bumi Aksara.

2010. Organisasi dan Motivasi. Jakarta: Bumi Aksara.

Ilyas . 2007. Organisasi, Perilaku, Struktur, Proses. Terjemahan Nunuk Adiarni. Jakarta: Bina Rupa Aksara.

La Sulo. 2005. Pengantar Pendidian. Jakarta: Rineka Cipta.

Mangkunegara. 2010. Evaluasi Kinerja SDM. Bandung: Refika Aditama.

Mulyasa. 2007. Kurikulum Tingkat Satuan Pendidikan. Bandung: Rosdakarya. 2009. Standar Kompetensi dan Sertifikasi Guru. Bandung: Remaja Rosdakarya.

2014. Guru dan Implementasi 2013. Bandung: Remaja Rosdakarya.

Mustafa. 2015. Pengaruh Karasteristik Individu Self Leadership, Rekan Kerja dan Tekanan Pekerjaan terhadap Perilaku dan Kinerja Guru di Sulawesi Barat.Disertasi.

Pujirahayu. 2008. Analisis Pengembangan Sumber Daya Manusiadalam Upaya Peningkatan Pelayanan Masyarakat pada Aparatur Sekretariat Daerah. Tesis.PPUMI Makassar.

Rivai. 2004. Performance Appraisal. Jakarta: Raja Grafindo Persada. 2005. Manajemen Sumber Daya Manusia Untuk Perusahaan. Jakarta: Raja Grafindo Persada.

Sadariah. 2016. Menjadi Pemimpin Sejati dari Teori ke Praktek Dalam Perspektif Perubahan. Makassar: Bintang Selatan.

Samsudin. 2005. Manajemen Sumber Daya Manusia. Bandung: Pustaka Setia.

Saondi . 2010. Etika Profesi Keguruan. Bandung: Rafika Aditama.

Sergiovanni. 1991. The principalship : a reflective practice perspective. Boston: Allyn and Bacon.

Sugiyono. 2011. Metode Penelitian Kuantitatif Kualitatif dan R\&D. Bandung: Alfabeta.

Suryabrata. 2005. Psikologi Pendidikan. Jakarta: RajaGrafindo Persada.

Suharsimi A. 2006. Prosedur Penelitian Suatu Pendekatan Praktek. Jakarta: Rineka Cipta.

Soetjipto. 2007. Profesional Keguruan. Jakarta: Rineka Cipta.

Syofian S. 2014. Statistik Parametrik Untuk Penelitian Kuantitatif. Jakarta: Bumi Aksara.

Tajuddin M. 2010. Manajemen Sumber Daya Manusia. Makassar: Umitoha Ukhuwah Grafika.

Usman. 2009. Manajemen Teori Praktik dan Riset Pendidikan. Jakarta: Bumi Aksara.

Undang-Undang RI Nomor : 20 tahun 2003 tentang Sistem Pendidikan Nasional. Jakarta: Depdikbud RI. 
Undang-Undang RI Nomor : 14 Tahun 2005 Bab IV Pasal 20 (a) tentang Guru dan Dosen. Jakarta: Depdikbud RI.

Permendiknas Nomor: 41 Tahun 2007 tentang Standar Proses untuk Satuan Pendidikan Menengah .Jakarta: Depdikbud RI.

Winarsih. 2007. Manajemen Pelayanan. Yogyakarta. Pustaka Pelajar.

Yamin . 2010. Standarisasi Kinerja Guru. Jakarta: Gaung Persada. 